\section{Research Article}

(c) 2021 Chaiuk et al. This is an open access article licensed under the Creative Commons Attribution-NonCommercial 4.o International License (https://creativecommons.org/licenses/by-nc/4.o/)

Received: 3 June 2021 / Accepted: 26 July 2021 / Published: 5 September 2021

\title{
Celebrities and Microcelebrities in Quarantine: Strategies of Parasocial Communication
}

\author{
Tetyana A. Chaiuk* \\ Iryna O. Alyeksyeyeva \\ Oksana V. Borysovych \\ Kateryna S. Karpova \\ Olena V. Gayevska \\ Taras Shevchenko National University of Kyiv, \\ Volodymyrska St, 6o, Kyiv, o1033, Ukraine \\ *Corresponding Author
}

DOI: https://doi.org/10.36941/ajis-2021-0121

\section{Abstract}

The research applies the relationship strategies and the image repair strategies frameworks to study and compare celebrities and microcelebrities' communicative activity on social media during the lockdown in the USA and the UK in spring, 2020. For celebrities, the sample collected on social media in March - April, 2020, reveals qualitative changes: in the quarantine, first-rank celebrities attempted to reduce the assumed gap between themselves and their fans by using the strategies typically associated with microcelebrities, namely openness, positivity, task sharing, and assurance. If applied inappropriately, these strategies damaged the celebrities' image and the famous chose either to take corrective actions or to ignore the communication failure. The microcelebrities' messages during the lockdown did not show any qualitative shift: they held on to their typical openness, assurance and task sharing relationship maintenance strategies. Yet, the posts, where some microcelebrities, pursuing the openness strategy, sincerely reported their neglect of the quarantine restrictions, were more destructive to their image than similar posts from celebrities. The negative feedback affected microcelebrities communication on social media quantitatively and qualitatively: the number of messages dropped and the bloggers employed an extensive set of strategies to repair their image.

Keywords: celebrity, microcelebrity, parasocial communication, relationship maintenance strategies, image repair strategies

\section{Introduction}

The coronavirus pandemic is definitely what will make the year 2020 memorable for the overwhelming majority of the world's population: it has affected all the continents, interfered with all spheres of life and modified the perception of the present and the past (see (Ferreira, Serpa, \& Ferraz, 
2021)). Governments have chosen different strategies to cope with the pandemic: some, e.g., Italy, Spain, India, Great Britain, and Australia, introduced restrictions and literally confined citizens to their homes for a while, others preferred a more relaxed approach and let the usual course of life go on in the hope of natural active immunity. As of April 3, 3.9 bln people (i.e., half of the world's population) were asked or ordered to stay at home (Sanford, 2020). Those lucky ones who were able to work from home felt less under pressure since they were still employed, continued earning money and were kept busy. However, working (as well as studying) from home turned out to be a challenge: trapped for weeks in their flats or houses, family members who used to see each other relatively briefly in the morning and in the evening discovered how stressful it might be to spend side by side every minute of the lockdown period, to give each other physical and psychological space to work and to support each other in this time of uncertainty and anxiety (see, for example, (Alkhamshi, bin Shalhoubm, Hammad, \& Alshahrani, 2021)). The lockdown was indeed a one-off experience: no other epidemic, though quite a few they were, has brought to a standstill retail, educational institutions, domestic and international transportation.

This is when the Internet proved to be an irreplaceable invention. Within a couple of weeks, everything - work, studies, shopping, social life, entertainment - moved from the real to the virtual world (Bali \& Makki, 2021; Chaiuk \& Karpova, 2021). The Internet acquired the status of a life line that connects one to those beloved, or just to others. The advanced technology turned out to be better than any other media. Online communication provided participants with the feeling of immediacy. People discovered a range of applications that helped to a certain extent ease the lack of real-life meetings: business people, relatives, lovers and friends got together in Zoom, Skype, WhatsApp, FaceTime and so on.

War-like news filled with daily reports on COVID-19's lethality, politicians' speeches heralding a gloomy future (see (Alyeksyeyeva, Kaptiurova \& Orlova, 2020; Chaiuk \& Dunaievska, 2020)), the suffocating lockdown and financial uncertainty made audiences expose their inner selves and, consequently, gave people a chance to get to know each other better, to think back and to reconsider priorities. The lockdown proved to be a blessing in disguise for the famous: on the one hand, their potential audiences became larger, on the other hand, there was only one channel to reach out - social media. Thus, this research focuses on celebrities and microcelebrities' parasocial communication with their followers during the 2020 spring lockdown, namely their use of strategies aimed at maintaining relations with fans as well as their image repair strategies used in faux pas cases.

\section{Literature Review}

Research into celebrities and mass media communication differentiates between stars, celebrities and influencers. Stars usually derive significance from their roles, though their "real life" also determines the image. To show this duality, Dyer suggests the term star image to talk about the indistinguishable nature of the "star-as-person" and the "star-as-performer" (Dyer, 1998, p.6o).

In the $21^{\text {st }}$ century, however, the 'star' category has become too narrow to verbalize the social status, functions and mode of famous people's communication, so the term celebrity started to be used ever more. The evolution of this notion leaves no doubt: in 2001, Chris Rojek defines celebrity as "the attribution of glamorous or notorious status to an individual within the public sphere" (Rojek, 2001, p.10), which makes 'celebrity' synonymous to 'star'. Yet, further evolution of show business and mass media required elaboration of the 'celebrity' concept and its differentiation from that of the 'star': stars, typically seen as extraordinary and inaccessible people, have been replaced gradually by 'celebrities' who position themselves as quite approachable, knowable, and authentic. Compared to stars, celebrities appear "more disposable, less dignified and rooted in flimsier and more superficial modes of identity" (Leonard \& Negra, 2018, p.220). 'Celebrity' is defined by non-stop interaction with fans aimed at constructing a consumable persona and characterized by intimacy, authenticity and access (Marwick \& Boyd, 2011). The persona, or image built for the public eye, is the result of joint efforts made by the celebrity, agents, and PR people (Lui, 2013). In other words, the persona is a 
construct created by 1) the roles played by the celebrity in films or TV series, 2) the celebrity's personality exposed in talk shows, etc., and 3) the image, i.e., the shared idea of the celebrity established after a period of time (Jerslev, 2014). These are the components that in the long run transform celebrities into brands that enhance sales of products associated with the celebrities (Lunardo, Gergaud \& Livat, 2015; Younas, Farooq \& Khalil, 2018).

Joint efforts on the part of celebrities, their teams and the mass media produce the so-called 'celebrity culture', cultivated by all media forms. Celebrity obsession has given rise to new occupations, unthinkable in the times when the visual was secondary to the verbal, paparazzi being the best example. In the late $20^{\text {th }}$ century, the bulk of verbal and visual texts within celebrity culture gradually formed celebrity discourse that "moves through and shapes into media form a variety of types of news" (Marshall, 2014, p. 157). This discourse is the essence of celebrity culture interpreted as "a symbiotic business relationship from which performers obtain wealth, honors, and social power in exchange for selling a sense of intimacy to audiences" ("Celebrity culture", 2020).

While in the pre-social-networking era it was primarily mass media that decided what information on celebrities should be made public, social networks have finally given celebrities a personalized platform to build their personas and to communicate with their fans on a more personal basis. The term 'parasocial interaction' was coined by Donald Horton and Richard Wohl (Horton \& Wohl, 1956) to describe a psychological relationship an audience develops as a result of mediated encounters with celebrities on the mass media (initially, television was the primary medium that facilitated these relations). Interacting parasocially presupposes considering media performers as friends without ever meeting them personally. Parasocial relationships are illusionary for several reasons. Firstly, audiences are engaged in communication with personas rather than personalities. Secondly, audiences develop quite extensive knowledge of a celebrity without any reciprocity. It should also be mentioned that parasocial communication on social media exceeds TV-mediated communication in terms of immediacy and perceived personalization. This type of relations has a number of psychological and social consequences that have attracted experts' attention (see, for example, (Hartmann, 2016; Liebers \& Schramm, 2019; Stever \& Lawson, 2013)).

Instagram, YouTube, and Twitter have turned out to be a double-edged sword for celebrities, their self-promotion and celebrity culture. On the one hand, celebrities now enjoy more control over the media coverage of their work and life stories than they used to at the time of printed magazines and TV: social media are more reliable mediators than other channels in cases when celebrities intend to get closer to their audiences by uploading close-ups or tours of their homes. These techniques manipulate the audiences to believe that they are in intimate contact with the famous and that the famous actually are not that different and unapproachable (see, for example, (Kowalczyk \& Pounders, 2016)). On the other hand, by dispelling the myth of celebrities' exceptionality, social media have opened Pandora's box of vanity and obsession with fame. Up till quite recently, to become known, one had to have an outstanding skill, competence or ability and these had to be noticed by media companies that own the means to broadcast this skill, competence or ability to the world. Social media have changed the scheme and given the floor to microcelebrities (also called influencers, or bloggers). The crucial difference between celebrities and microcelebrities lies in that, while celebrities exploit their fame to launch video channels or pages on social media, influencers use these channels to become celebrities (Berryman \& Kavka, 2017).

To define social media influencers (SMIs), however, is not an easy task because they "oscillate between intimacy and publicity, authenticity and commercialization, ingratiation and critical distance" (Borchers, 2019, p.255). In general, SMIs are "a new type of independent third party endorser" who, having established a significant number of relationships, juggles "the roles of intermediary, content distributor, creative content producer, community manager, testimonial, strategic counsellor, and event host" (ibid., p.255). The influence on audience's attitude is exercised through blogs, tweets, and the use of other media (Freberg, Graham, McCaughey \& Freberg, 2010, p.1). In its essence, the content produced by SMIs is perceived as authentic and may be conveyed via numerous platforms and formats, e.g., texts (blogs), pictures (Instagram), videos (YouTube), and live streaming (Twitch). 
Research into SMIs started in the mid-2ooos and focused on blogs that provided audience with news. At the initial stage, bloggers were regarded as new actors in public discourse that modified the public sphere (see, for example, (Carlson, 2007; Wallsten, 2008)). The audience of those bloggers turned out to be young educated upper-class men (Kaye, 2005).

The term 'microcelebrity' introduced by Senft seems to be more relevant than SMI. Senft defines microcelebrity as a type of celebrity that is characterized by a "commitment to deploying and maintaining one's online identity as if it were a branded good, with the expectation that others do the same" (Senft, 2008, p. 346). Thus, microcelebrity is interpreted as a communicative practice, a "way of thinking of oneself as a celebrity, and treating others accordingly" (Marwick, 2013, p. 115). Researchers point out that, while mainstream celebrities rely on distancing strategies that distinguish the celebrity rather than on striving to relate to their audiences as equals, microcelebrities do their best to connect with other social media users by successfully managing the self as spectacle (Hearn, 2008; Jerslev, 2016).

The modern public discourse on social media generated by celebrities of various calibre has opened up a new field, Celebrity Studies, whose issues are discussed at annual conferences (see, for example, (Andt \& Corsini, 2019)). The problems of strategic communication within this type of discourse include the issue of self-branding (Khamis, Ang \& Welling, 2017), relationship building (García-Rapp, 2017), establishing intimacy (Abidin, 2015) to name just a few.

\section{Theoretical Framework}

This study views any communication as inherently strategic, i.e., participants plan every interaction in order to achieve a certain goal. Planning may be conscious (in case the goal is of utter importance or the communicative situation is unconventional, e.g., request for a pay rise, declaration of love) or unconscious, automatic, as it is in casual or ritualized encounters. A communicative strategy is determined by participants' objective and may change as a reaction to their partner's feedback. Messages sent by celebrities and microcelebrities to their fans are strategic and function as a means to implement relationship maintenance and/or image restoration strategies.

Though relational maintenance seems to be an unambiguous term, its definitions may differ. Dindia and Canary (1993) point out that relational maintenance may denote one of the following: (1) maintenance aimed at keeping the relationship in existence; (2) maintenance aimed at preserving the status quo; (3) maintenance that involves development of the relationship; (4) maintenance aimed at repairing the relationship (Dindia \& Canary, 1993). It is worth noting that all the four definitions are grounded on the purpose people pursue while maintaining their relations and there is a rather vague borderline between the first and the second definitions because, all in all, they imply stability as the target of relationship maintenance, so they may be treated as one. The fourth definition relates maintenance to conflict management and image restoration.

The theoretical background to study relationship maintenance is provided by Stafford and Canary (1991) who distinguish five relationship maintenance strategies: positivity, openness, assurance, social networks and sharing tasks (Stafford \& Canary, 1991). The strategies are actualized with the help of tactics that, in their turn, are communicated verbally and non-verbally. The positivity strategy, for example, is carried out with the help of cheerful behaviour and avoidance of critical remarks (Stafford \& Canary, 1991; Canary \& Stafford, 1992). In 2011, Stafford came up with a new typology of relationship maintenance strategies that comprised of positivity, assurance, understanding, relationship talk, self-disclosure, social networks, and sharing tasks (Stafford, 2011). In this study, the 1991 typology is applied because self-disclosure presupposes much more intimate communication than openness and it is openness that is observed in parasocial interactions.

The Image Restoration Theory has been elaborated by Benoit (see, for example (Benoit, 1995; Benoit \& Hanczor, 1994; Benoit \& Pang, 2008)). The researcher believes that, since attacks or complaints that undermine one's reputation consist of the claim that the accused is responsible for an action and that the action is offensive, image repair strategies should be classified on the ground of the component addressed by the accused in order to defend themselves. Thus, the accused may turn to 
a) denial, i.e., the accused denies that the act has actually taken place or deny the responsibility for the act (blame shift)

b) evading responsibility for the act by saying that the act resulted either from a provocation, or lack of knowledge (ability), or an accident, or was a well-meant action that ended in a failure reducing offensiveness that may be achieved through bolstering one's positive reputation, minimizing the seriousness of the wrongdoing, differentiating the wrongdoing from worse actions, transcendence, i.e. placing the action into a less offensive frame of reference, attacking the accuser, or compensating for the damage afflicted

c) corrective action

d) mortification.

\section{Methodology}

The study draws on textual and visual analysis of parasocial communication maintained by celebrities and microcelebrities during the 2020 lockdown enforced in the USA and the UK. The restricting policies of the pandemic excluded any interactions except online, which had always been the usual medium for microcelebrities, yet it was the first time for first-rank celebrities to have social media as the only communication means.

The following questions drive this research:

RQ1. Did the lockdown change celebrities and microcelebrities' online communication in terms of its quantity (number and frequency of messages) and quality (topics)?

RQ 2. What relationship maintenance strategies did celebrities and microcelebrities use in their messages on social media? What topics did celebrities and microcelebrities bring up and how did they accommodate their messages to the lockdown circumstances?

RQ 3. What image repair strategies did celebrities and microcelebrities employ if their messages received negative feedback?

To obtain answers to these questions, the research was arranged into the following stages:

Stage 1. Since mass media play an important part in celebrities' promotion, on the one hand, and reflect their actual popularity, on the other hand, to narrow the number of the subjects whose messages would be analysed in the study, platforms Everyday Health, Gen, Insider, People, UsWeekly, Vanity Fair, Vox, and Vulture (e.g., (Cummins, 2020; Flanagan, 2020; Handler, 2020; Lustig, 2020; McArdle, 2020; Willen, 2020), etc.) were examined in search of celebrities and microcelebrities that got media coverage for their messages on social media within the period of March - May, 2020. As a result of this stage, 20 celebrities and 5 microcelebrities were chosen as subjects of the research.

Stage 2. The social media activity of the selected celebrities and microcelebrities in March 1 April 30, 2019, and in March 1 - April 30, 2020, was explored, which produced a sample of 2544 texts on Instagram, 1938 texts on Twitter, and 196 videos on YouTube. Collecting the sample was also accompanied by taking into account such data as the number of views and audiences' comments.

Stage 3. The texts produced by the celebrities within the same period were analysed quantitatively. The quantitative analysis was followed by the qualitative examination of their content in order to identify changes, if any, and their causes.

Stage 4. The celebrities and microcelebrities' messages from the sample were examined within the framework of relationship maintenance strategies (Stafford \& Canary, 1991).

Stage 5. In case of the audience's negative feedback, the celebrities and microcelebrities' further messages (e.g., posts on social media as well as messages conveyed via other media channels) were analysed and classified within the framework of Benoit's image repair strategies (Benoit, 1995; Benoit \& Hanczor, 1994; Benoit \& Pang, 2008). It should be noted here that this stage involved using mass media publications as sources to retrieve the subjects' infelicitous posts, since some celebrities and microcelebrities chose to delete scandalous messages from their pages as an image repair strategy, which rendered impossible an immediate access to these posts. 
Stage 6. The communication patterns employed by celebrities and microcelebrities in order to keep in touch with their audiences or/and restore the image during the 2020 lockdown were compared and the results interpreted.

\section{Results}

Modern Western society shows a remarkable rise in the interface between celebrities and their audience: fans expect two-way communication with the famous who, in their turn, play a remarkable role "in the circulation and modulation of social affect" (Leonard \& Negra, 2018, p.219). Though the Internet had changed communicative patterns at the both ends of the communication chain before 2020 , it is the year 2020 that saw a dramatic increase in online communication: the coronavirus pandemic resulted in the lockdown in the USA and the UK and quickly transformed the Internet into the medium that provided people with a chance to talk and see each other with the help of various platforms. It was only natural that celebrities and microcelebrities, deprived of any other channel to become visible, grabbed the chance to use the Internet to maintain relations with their audiences.

\subsection{Quantitative and Qualitative Analysis of the Sample}

The sample has revealed that the frequency of messages produced by celebrities during the lockdown remained approximately unchanged: Madonna, for example, made 95 posts on Instagram in March April, 2019, and 80 posts during the same period in 2020; the data for Reese Witherspoon's Instagram activity are 59 and 41 , respectively.

The results are, however, drastically different for two celebrities: Lady Gaga left only 2 posts in March - April, 2019, but there were 31 messages in 2020; the data for Kristen Bell are 34 in 2019 against 109 in 2020. The reasons for the dramatic increase lie in the circumstances: the lockdown interfered with Lady Gaga's release of the Chromatica album (it was scheduled for April 10, yet came out May 29, 2020), so the majority of the singer's posts aimed at keeping the audience interested in the postponed album.

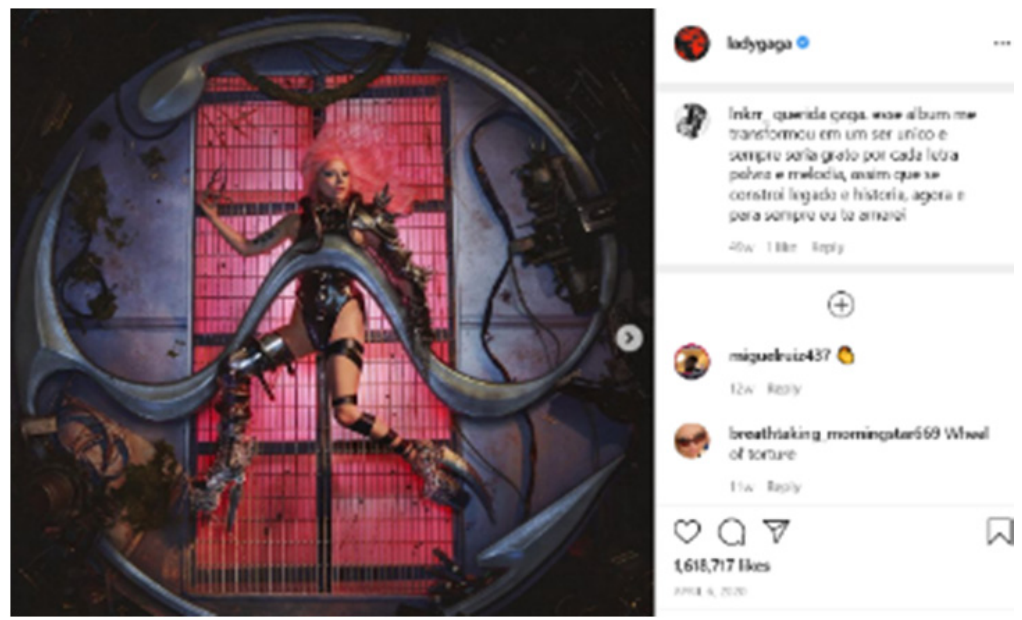

Figure 1: Lady Gaga \#Chromatica 2020 (2020, April 6)

Kristen Bell's online activity during the quarantine may be attributed to her active engagement with social and charity work: she intended to alleviate isolation, uncertainty and anxiety by keeping company and sharing some advice with her audience. 
This brings the research to examine the qualitative aspect of the sample. It is important to mention that even if the number of celebrities' publications remained roughly the same, the content got heavily influenced by the pandemic: besides self-promotion posts that used to domineer her Instagram, Madonna, for example, uploaded messages that let the audience into her home as well as started Quarantine Diaries (14 posts) to disclose her perception of the lockdown life; Reese Witherspoon, in her turn, published \#ShineOnatHome Conversations in an attempt to help her followers cope with the distress of the quarantine.

Microcelebrities normally upload one message a day (for example, Naomi Davis and Ali Maffucci published 62 and 69 posts in March - April, 2019). Yet, if a microcelebrity builds an image of fashionista like Arielle Charnas, the number of posts within the same timespan may be twice as high (139 messages within 61 days in 2019). Since the bloggers from the sample capitalize on showing their everyday family life, the lockdown was unlikely to alter the frequency of their communication and to influence its content. Yet, the sample reveals that in March - April, 2020, Naomi Davis and Arielle Charnas produced only 25 and 27 posts. The further analysis shows that the drastic drop is related to the scandals these two bloggers got involved in and the backlash they tried to handle.

\subsection{Relationship Maintenance Strategies Used by Celebrities}

The onset of the quarantine was definitely a challenging time for the famous because, to avoid oblivion, they had to stay in touch with their audiences while the only channel to maintain this relationship was the Internet. Since ordinary people were filled to the brim with worries about their beloved ones and anxiety over the future, the topic of the epidemic all of a sudden overshadowed any other news, be it Brexit or new shimmer-free highlight balm.

At the initial stage, celebrities split into two groups in their choice of communicative behaviour. The majority demonstrated that they took the pandemic seriously, supported the lockdown and plunged into the new shelter-in-place lifestyle. The dominant maintenance strategies here became those of openness, positivity and sharing tasks: celebrities opened up their quarantine routine for audiences, reported good mood and went to great length to convince their fans that their routine was very similar to everyone else':

Lady Gaga posted a photo on Instagram showing herself playing video games and cards with her boyfriend Michael Polansky and adding the captions: Day 6 of self-quarantining! Going strong, playing video games and cards, and taking care of ourselves. Important reminder: keep your mind as stress free as possible and your body moving. \#selflove \#selfcare \#bekind try not to pass it in case you have it \#corona it's ok and so wonderful to stay home if you can! What a kind act for the world $\bullet$ (Lady Gaga, 2020, March 18)) (Fig.2)

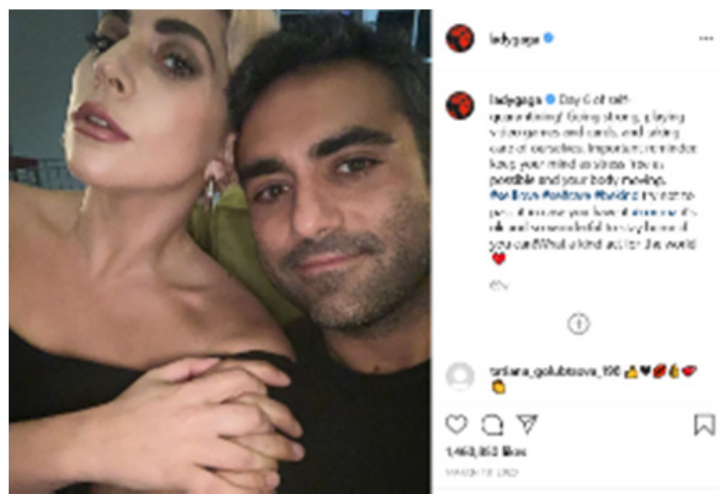

Figure 2: Lady Gaga. Day 6 (2020, March 18) 
Kristen Bell used Instagram to show her followers how she kept her children entertained (Heres a cool coloring project we all just did! \#flattenthecurve (Bell, 2020)) (see Fig.3).

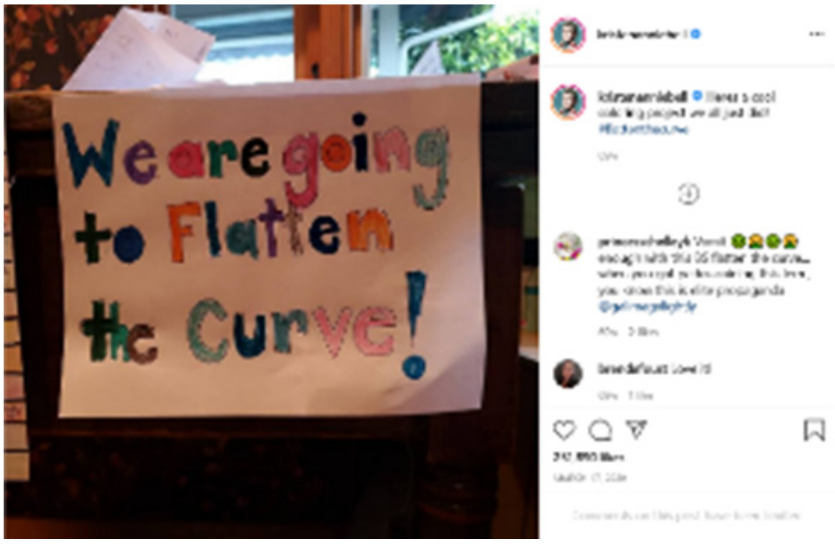

Figure 3: Kristen Bell's coloring project

Cardi B uploaded the video of the giant Jenga she built and wrecked in one go, adding the eloquent Day 3 on her Instagram page The video got over $28.4 \mathrm{mln}$ views, while the number of views normally varied from 5 to 19 million (Cardi B, 2020) (Fig. 4).
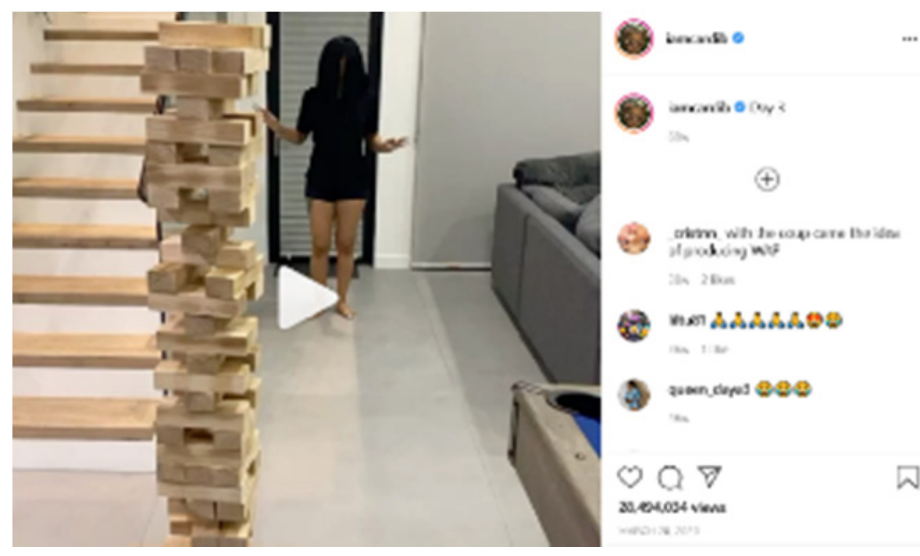

Figure 4: Cardi B’s Day 3

Celebrities viewed compliance with the new restricting rules as an important message to be communicated: Reese Witherspoon, for example, uploaded the photo of her walk with Laura Dern, when the two kept the social distancing requirement. Still, careful Reese did not forget to mention that the walk had taken place BEFORE the lockdown: Friendship with social distancing. Hi @lauradern! We walked a few days ago .. before we were told to \#stayhome. Now we are inside to keep everyone safe (Witherspoon, 2020) (Fig.5). 


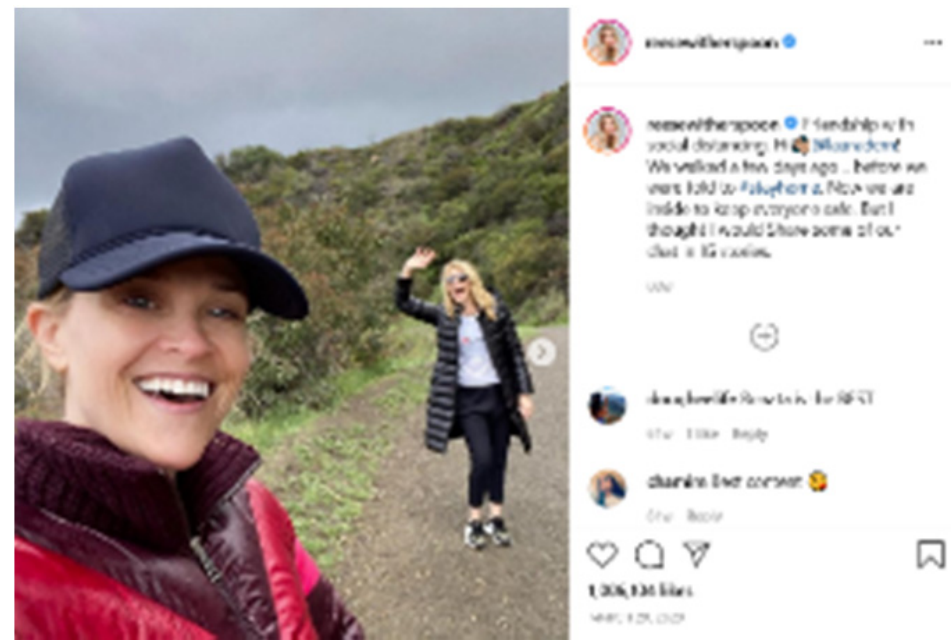

Figure 5: Reese Witherspoon's Friendship with social distancing

Entertaining and following the social distancing instructions were not the only tasks to be shared. Celebrities also reported more serious occupations and tried to get their audiences engaged by asking for their feedback. Nicole Richie, for example, posted a photo of the books she was going to read (These are my lockdown plans. Please send me 9 thousand more recommendations. (My recommendations to you are The Great Alone, E The Hearts Invisible Furies). Also shows and movies. Just entertain me dammit! (Richie, 2020). Shakira informed her fans of the completion of a course on Ancient Philosophy and posted a photo of herself and the course certificate: I just graduated from my 4 week Ancient Philosophy course with the University of Pennsylvania (@Penn). I know... my hobbies are very impractical, but it took a lot of hours after the kids were asleep. Thank you Plato and predecessors for all the "fun" over the past month! (Shakira, 2020). These messages, besides exposing private lives and optimism, openly encouraged to follow the quarantine rules and explicitly or implicitly invited to join the celebrities in the activities.

It should be noted that the most of openness was demonstrated by those famous people who contracted the virus and documented their illness and recovery (here belong, for example, Tom Hanks, Rita Wilson, and Chris Cuomo). Since COVID-19 is viewed as dangerous, these sincere and audience-oriented reports were highly appreciated by the public.

Some celebrities employed the openness strategy inappropriately by either denying the coronavirus or showing an attitude different from the conventionally acceptable. Those who wouldn't acknowledge the seriousness of the pandemic and did not hesitate to express this on their pages were the first to get their audience's thumb-down. Here belongs Elon Musk: on March 6, he tweeted, "[t]he coronavirus panic is dumb" (Musk, 2020a). A week later, he came up with the tweet "[f]ear is a mindkiller" (Musk, 202ob) (see Fig. 6). In both messages he implied lack of critical thinking in those who took the virus seriously. 


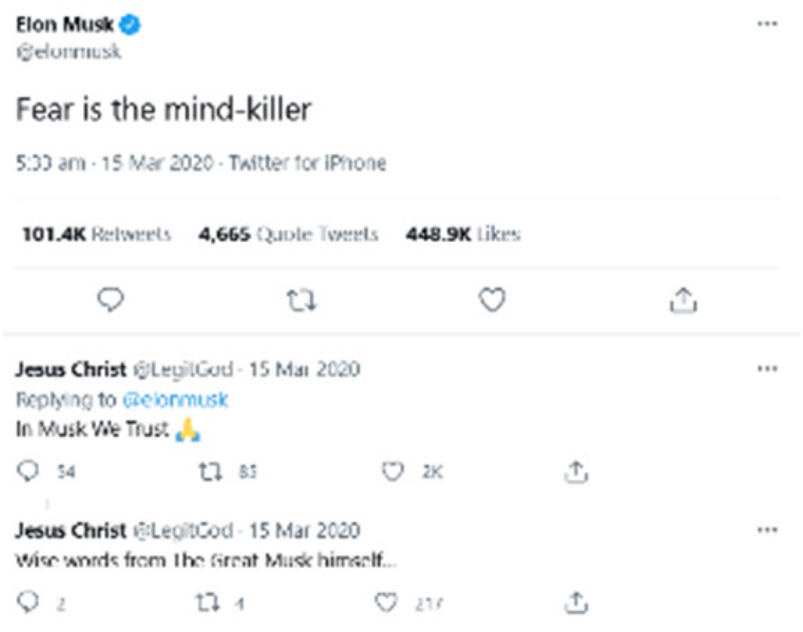

Figure 6: Elon Musk's tweet

Vanessa Hudgens unintentionally challenged the public by taking lightly numerous victims of the coronavirus in her Instagram post on March 16. What she said was, literally, "I'm sorry, but like, it's a virus, I get it. I respect it. But at the same time, like, even if everybody gets it, like, yeah, people are gonna die. Which is terrible, but like, inevitable?" (the video is accessible in (BBC News, 2020)). The audience was quick to denounce the attitude to human lives.

The pandemic exposed and deepened the 'rich vs poor' divide. It is the idea of social inequality that primed audiences to react negatively to some celebrities' attempts at the openness strategy that unwittingly exposed celebrities' extravagances and superior living conditions. Sam Smith, for example, reached out to share his emotions and uploaded photos of depressed himself on Instagram with the title Stages of a quarantine meltdown (the photos are accessible in (Kavanagh, 2020)): the audience did not join in shedding tears together with the celebrity confined in his luxurious house. It should be noted that media poured oil into the flames by publicizing heroism of 99-year-old World War II veteran Captain Tom Moor, who "raised almost \$30 Million for the NHS by walking 100 laps in his garden unaided" (Lustig, 2020).

Madonna kept in touch with her fans by uploading quarantine diaries where, on March, 22, she called the virus "the great equalizer", adding that it "doesn't care about how rich you are, how famous you are, how funny you are, how smart you are, where you live, how old you are, what amazing stories you can tell" (Lustig, 2020). The attempt to get closer to the audiences failed due to the setting chosen by the superstar for the video: she was lying in a milky bath sprinkled with rose petals. The singer's followers pointed out in their comments that though the coronavirus did not discriminate, life was hard outside Madonna's mansion, and suggested her being more empathetic.

Jennifer Lopez who shared on Instagram her domestic life during the confinement also provoked negative feedback when she uploaded a video of her 12-year-old son serving a can of Perrier to her boyfriend. The cherry to crown it all was Lopez' comment We can't go out to any restaurants or anything but the service and entertainment here is pretty good... \#StaySafe \#familytime (Lopez, 2020) (Fig. 7). The message was received negatively because, as some noted, though \#stayhome related to everyone, some homes were mansions with lime green backyards and swimming pools while others were tiny flats. 

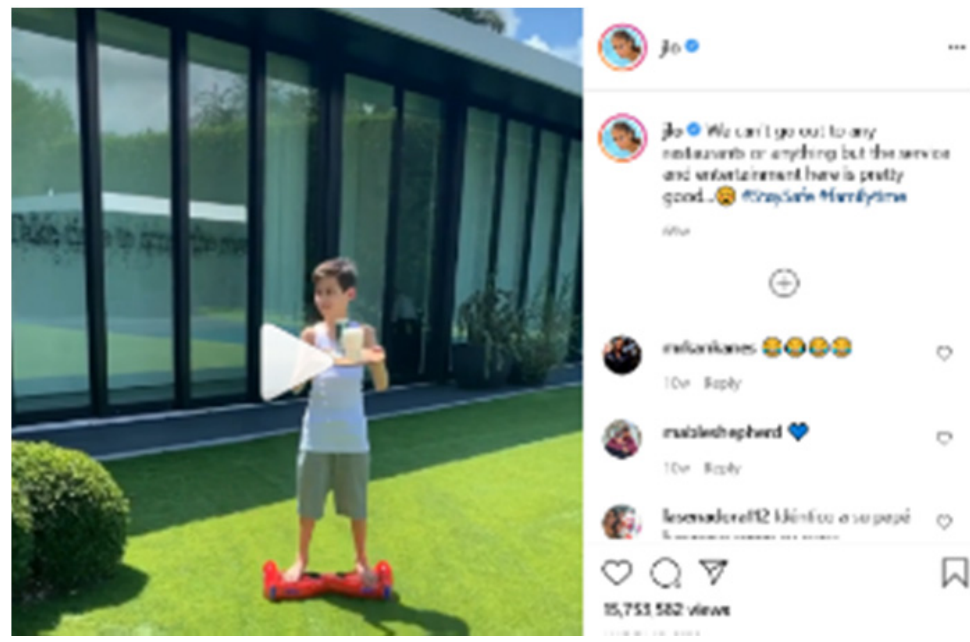

Figure 7: Jennifer Lopez’ post

Online events arranged by celebrities for their audiences actualized the assurance strategy: they engaged people, distracted them from the lockdown boredom and communicated the message of celebrities' sincere involvement with their fans. Celebrities carried on working without any financial gain (for example, John Legend streamed his concert on Instagram, while Miley Cyrus launched the livestream where she interviewed other celebrities, e.g., Demi Lovato, Rita Ora, Jeremy Scott, etc.).

Performing online, however, did not always produce the desirable effect. The most remarkable communication failure in the quarantine and the one that involved the most celebrities and got the worst publicity was probably Gal Gadot's video. The actress brought together 21 famous people and planned to deliver the message of solidarity to the general public by singing John Lennon's Imagine. Yet, the performance brought about a wave of mockery and resentment because it was out of sync with the audience's concerns: people wrote that it was easy for them to imagine 'having not possessions' because that was exactly where they found themselves during the economic crisis caused by the lockdown. The comments below the video ranged from How disconnected from reality $\mathrm{r}$ these people to Dear celebrities, We hate you. The people (ET Canada, 2020).

Jaime King, in her turn, tried to align with the public by reciting the poem by Riya Sokol Thank You, Coronavirus. The writer expands on the good the pandemic has done to people: the danger makes everyone prioritize relations over trifles and think about the environment and interconnectedness of everyone and everything. In short, the author thanks the virus for "undermining everything and giving us a chance to build a world from the very beginning" (the video is accessible in (Willen, 2020)). The message of the poem was as incompatible with the public mood as Lennon's song and received hostile remarks.

It should be noted that small details of symbolic or metaphoric nature gained much importance and were scrutinized to the minute detail. On March 22, for example, Sia uploaded an ambiguous image that was not accepted favorably because crossing out vir in virus implied everyone's involvement, vulnerability and insecurity (see Fig.8) (Sia, 2020). In fact, it gave off ill fate: 


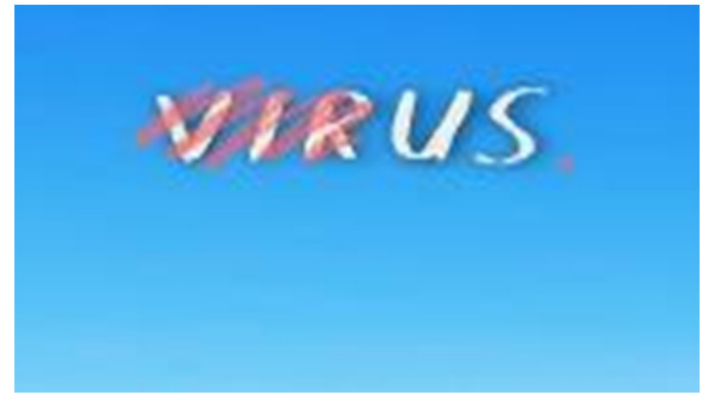

Figure 8: Sia’s post

Another form of the assurance strategy was used by Rihanna, Taylor Swift and Cardi B who expressed their empathy by donating millions of dollars to charities that help people trapped inside with abusive partners as well as fans who lost their jobs during the lockdown (Noor, 2020). Taylor Swift, for example, sent her donation to an unemployed fan with a compassionate note whose text was made public: "Erin, I saw your tweets about the financial and emotional stress you're under right now and it made me want so badly to help. I'm so sorry about your job and the uncertainty of what's going on right now. I hope this gift of \$30oo will help. I loved meeting you in New York and I hope you're safe and healthy! Your pal, Taylor" (Rowley, 2020).

Unlike celebrities, microcelebrities did not have to change their medium or communicative behaviour during the lockdown. Their relations with the followers thrive owing to the openness, sharing tasks, and assurance strategies and their communication is much more two-way than communication of celebrities who mostly ignore their fans' comments (Nouri, 2018) since they are "everyday, ordinary Internet users whose lives "as lived" are the central themes of their output, wherein followers are privy to what appears to be genuine, raw, and usually inaccessible aspects of influencers' personal lives" (Abidin, 2015, p.7). Taking into account these factors, their popularity with audiences was secure and they went on following their usual communication patterns.

Yet, some microcelebrities undermined the assumption of their 'ordinariness' as well as the assumption of their exemplary lifestyle, the two pillars of their popularity, when they shared with their followers how they violated the lockdown restrictions. For example, Naomi Navis, a mother of five, and her husband escaped locked-down New York in an RV to keep her family's mental health and to give her children a chance to go outdoors and reported the move on Instagram (the photo of the RV is still uploaded, the text to go with the photo has been changed after the followers' backlash (Navis, 2020)) (see Fig. 9).
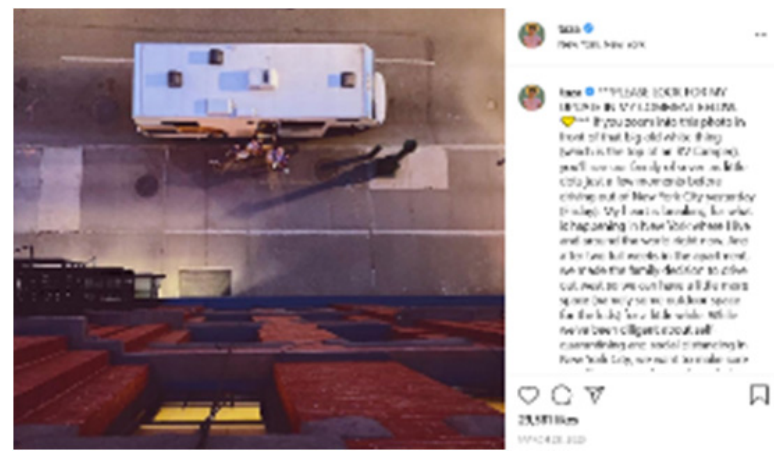

Figure 9: Naomi Navis' post about leaving New York 
So did another microcelebrity, Ali Maffucci who drove from New Jersey to Florida during the lockdown. This move was interpreted by the followers as a thoughtless, anti-social action that put at risk many other people because travelling by an RV did not exclude getting out at petrol stations and spreading the virus. The move was criticized by the public as we can see in Fig. 10, yet the disapproval did not affect the microcelebrity's communication pattern in any way.
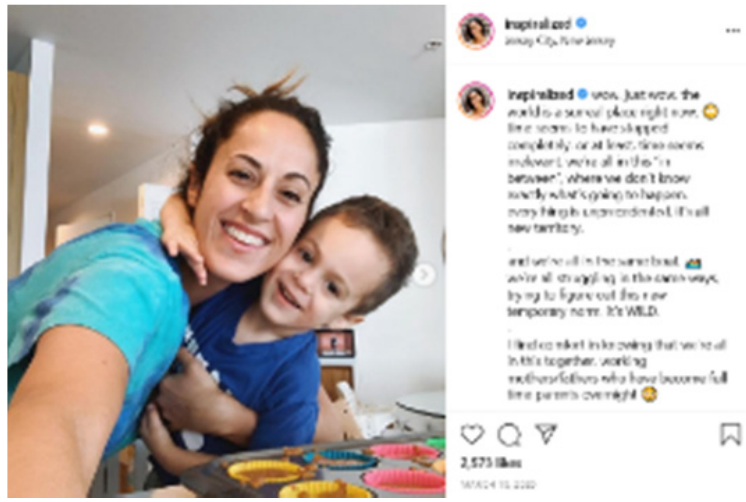

Figure 10: Ali Maffucci's post and the comments she got after her move to Florida during the lockdown

Arielle Charnas, another Instagram blogger, expanded on her careless steps that annoyed her followers. First, she used her connections in a hospital to have a drive-through test at the time when many Americans could not get these services easily no matter how much they needed them. Then, after the test turned out to be positive, she, instead of self-isolating at home, retreated to the Hamptons with her family and nanny. The photos of herself enjoying sunshine at the expensive resort and hugging her kids just days after revealing her diagnosis fueled her followers' indignation.

Some microcelebrities, thus, were carried away with the openness strategy at the expense of task sharing.

\subsection{Image Repair Strategies}

In cases of negative feedback or face loss, celebrities and microcelebrities turned to different image repair strategies.

Some celebrities, namely those who could be called stars in its conventional meaning, did not take any steps to restore their damaged reputation. In other words, they did not respond to negative or even hostile comments, neither did they upload any messages that might explain or whitewash their previous posts. This was, for example, Jennifer Lopez' behavior.

A somewhat different course of actions was chosen by Madonna and Jaime King, who did not offer any excuse or explanation but deleted the ill-famed content.

Those celebrities who tried to redress the damage verbally preferred to admit their mistakes but tried to avoid responsibility by claiming that their unfortunate posts resulted from extreme anxiety and insecurity of the first days of the lockdown (defeasibility strategy) as well as their willingness to share and solidarize with the audience (good intentions strategy). They also attempted to reduce offensiveness of their actions by stating that they followed all the quarantine rules (corrective actions) and by accusing their critics of distorting either the message or the celebrities' intentions (counterattack strategy). Thus, on March 17, Vanessa Hudgens uploaded a video on Instagram where she said: 
I realize today that some of my comments are being taken out of context [counterattack]. It's a crazy time. It's a crazy, crazy time [defeasibility]. I am at home and in lockdown [corrective action], and that's what I hope you guys are doing too - in full quarantine and staying safe. Yeah, I don't take this situation lightly by any means. (See the video in (BBC News, 2020))

Hudgens also posted a tweet where she combined image repair strategies with relationship maintenance:

Hey guys. I'm so sorry for the way I have offended anyone and everyone who has seen the clip from my Instagram live yesterday [apology]. I realize my words were insensitive and not at all appropriate [mortification] for the situation our country and the world are in right now. This has been a huge wake up call about the significance my words have, now more than ever. I'm sending safe wishes to everyone to stay safe and healthy during this crazy time [assurance]. (Hudgens, 2020)

In response to the backlash of his Instagram "quarantine meltdown" photos, Sam Smith said on the Heart Breakfast radio show:

It was six weeks ago I posted a picture and everyone else was posting pictures. It was probably bad timing of me [defeasibility], but I use my social media as if it's just my friends on it. I posted with my humour and stuff, but it just didn't get picked up very well, but I didn't mean any malice by it at all [good intentions]. You know me, I'm always sharing all of my feelings all the time and trying to be as human as possible [bolstering] but sometimes maybe people can read it wrongly [counterattack] but that wasn't really meaning it in a malicious or nasty way, I was just trying to be myself [good intentions]. (See the video in (On the Radio, 2020))

A peculiar approach to dealing with the damaged image was chosen by Chris O'Dowd and Jamie Dornan who participated in the infamous Imagine video. O'Dowd accepted the criticism of the video itself but preferred to distance from it: he lacked any information about the context of the video (defeasibility) and he participated only because he was asked by a trusted friend, Kristen Wiig (blame shift):

I think the backlash is justified. I have to say, the next morning I was like, "God, what's this Imagine thing?" It had happened so quickly the day before where I was running from one kid to the other and I was walking through the garden and they said, "Oh, you have to do a video for Gal Gadot... I'll do anything Kristen asks me to do, so of course we just did it. It took five minutes, I didn't think about it. I presumed it was for kids..." (BBC Comedy, 2020)

The same strategies of defeasibility and blame shifting were employed by Jamie Dornan when he was interviewed by Shane Todd in Tea With Me show (Todd, 2020).

As for microcelebrities, who used to capitalize on their followers' assumption of sameness, they had to make efforts to redress the situation and employed a variety of strategies.

Naomi Davis, for example, posted a report on all the precautions her family was taking on their way, i.e., she implied sharing the same reality as anyone else with the only difference - in an RV rather than in an apartment. She also used the transcendence strategy to justify her behavior, "I don't know if this explanation helps but I am trying to do my best to take care of my kids and my family" (as cited in (Conley, 2020)).

Arielle Charnas replied in a much more emotional way: she made a video where she, a guru of IG look, in tears and without any makeup, said:

I'm sorry, I never in a million of years wanted to hurt anyone and we are not bad people. I'm sorry for anyone that I've offended or hurt over the last couples of weeks. We're just trying to navigate through these difficult times I'm sure so many are. I'm just sorry if I let down my community in any way. And just right now I'm trying to focus on my family because we've been receiving horrible threats. And I just felt it was time for me to share my truth, which I did. And it's now every effort to do the right thing throughout 
this process. (the video is accessible in (Greenspan, 2020)).

In this speech, the influencer apologizes three times (I'm sorry) as well as employs bolstering (we are not bad people), and transcendence (I'm trying to focus on my family). To enhance the effect, she finishes her speech by expressing her concern and good wishes to everyone who watches the video (assurance strategy used to keep the relations going): So, anyway, I'm thinking of you all and I hope everyone stays safe and healthy.

\section{Discussion}

The research reveals that, deprived of almost any other means of communication but social media, celebrities used these channels to maintain relations with their fans and enhance their image by combining the openness, task sharing and positivity strategies in their uploads. Communicating within the openness and task sharing strategies, celebrities produced "diary-like" texts and tried to maximize similarities of their lockdown routine with that of their followers. The verbal and nonverbal means of their messages supported the mainstream discourse on coronavirus and complied with the lockdown restrictions. The content of the messages ushered the followers into the celebrities' private life in quarantine; the hashtags implied that the celebrities, just like everyone else, followed the restrictions imposed by the government and urged everyone to do the same.

Celebrities used online events as means to implement the assurance strategy: online shows of various types promoted celebrities, their brand and their content, kept their audiences informed of new content as well as were similar to selfless donations. Another form of the assurance strategy was charity actions designed to help the fans who experienced hardship as a result of the lockdown.

The strategy of openness was not effective if celebrities expressed opinions different from the mainstream one, if celebrities flouted the lockdown restrictions, i.e., blatantly refused to 'share the tasks', or if celebrities' openness revealed social inequality.

To repair the damaged reputation, celebrities preferred corrective actions: they removed the unfortunate post from public access or redressed communicative failures by apologizing and avoiding responsibility, i.e., they justified their mistakes with good intentions or wrote them off to lack of information or inability to act appropriately in the time of uncertainty.

Microcelebrities, in their turn, rise to fame by exploiting the 'ordinary person' persona; unlike celebrities who become famous by showing some extraordinary abilities or talent, social media influencers do not need to be anyone special and are tightly bound to the mainstream culture: they thrive on the openness, assurance and task sharing strategies. In other words, the lockdown did not interrupt the customary communication pattern between microcelebrities and their followers.

In their posts, some SMIs, however, undermined their 'ordinary person' image, exposed their privileged social position as well as failed to show task-sharing behaviour, which was treated by the followers as antisocial. Communicative failures were more difficult to handle for the bloggers. In several cases, the microcelebrities disappeared from the social media for some time, which was not observed with the celebrities from the sample. To whitewash their reputation, the microcelebrities turned to the same strategies as celebrities but also employed the transcendence strategy: they justified their wrongdoings by concern for their families, first of all the children.

\section{Conclusion}

The research has revealed that, during the 2020 lockdown, the differences between public relations online activities of celebrities and microcelebrities were to a large extent levelled: first-rank celebrities adopted microcelebrities' maintenance strategies of openness and task-sharing in order to keep in touch with their fans, which reduced the perceived social distance between the stars and their audiences. These strategies brought about communication failures mostly when messages of the famous exposed social inequality. 
Though maintenance strategies converged, image repair strategies of celebrities and microcelebrities showed divergence: celebrities in the sample took communicative failures more easily, their behaviour ranged from ignoring people's negative feedback to counterattacking their audiences and accusing them of misinterpretation, while microcelebrities tended to invest many efforts to restore their image, in particular, by applying transcendence strategy and to repair their relations with the followers.

\section{References}

Abidin, C. (2015). Communicative intimacies: Influencers and perceived interconnectedness. Ada: A Journal of Gender, New Media, \& Technology, 8, 1-18. Retrieved August 14, 2020, from http://adanewmedia.org/2015/11/issue8-abidin/

Alkhamshi, S. S., bin Shalhoubm, H. abdulrahman, Hammad, M. A., \& Alshahrani, H. F. (2021). Covid-19 Pandemic: Psychological, Social and Economic Impacts on Saudi Society. Academic Journal of Interdisciplinary Studies, 10(3), 335-346. https://doi.org/10.36941/ajis-2021-0o88

Alyeksyeyeva, I., Kaptiurova, O., \& Orlova, V. (2021). World War Flu: War Rhetoric of the Australian Prime Minister on Coronavirus. 3L: The Southeast Asian Journal of English Language Studies, Vol 27(1), $90-101$. http://doi.org/10.17576/3L-2021-2701-07

Andt, R., \& Corsini, F. (Eds.). (2019). Desecrating Celebrity. Proceedings of the IV International Celebrity Studies Journal Conference. Roma: Edizioni Nuova Cultura. Doi: 10.4458/2719

Bali, A. O. \& Makki, A. (2021). The Use of Social Media as a Platform in Education: Ramifications of COVID-19 in Iraq. Academic Journal of Interdisciplinary Studies, 10 (3), 394-408. DOI: https://doi.org/10.36941/ajis-20210093

BBC Comedy. (2020, June 30). Chris O’Dowd on *THAT* Imagine video |Grounded with Louis. [Facebook status update]. Retrieved August 25, 2020, from https://www.facebook.com/bbccomedy/videos/267751614444374

BBC News. (2020, March 18). Coronavirus: Vanessa Hudgens sorry for 'people are going to die' comments. Retrieved August 23, 2020, from https://www.bbc.com/news/newsbeat-51941986

Bell, K. [@kristenanniebell]. (2020, March 17). Heres a cool coloring project we all just did! \#flattenthecurve. [Instagram]. Retrieved August 25, 2020, from https://www.instagram.com/p/BgoEc6yJ_YF/

Benoit, W.L. (1995). Accounts, Excuses, and Apologies: A Theory of Image Restoration Strategies. Albany, NY: State University of New York Press.

Benoit, W.L., \& Hanczor, R.S. (1994). The Tonya Harding controversy: An analysis of repair strategies. Communication Quarterly, 42, 416-433.

Benoit, W.L., \& Pang, A. (2008). Crisis communication and image repair discourse. In Tricia L. Hansen-Horn \& Bonita Dostal Neff (Eds.), Public Relations: From theory to practice (pp.244-261). Boston, MA: Pearson.

Berryman, R., \& Kavka, M. (2017). 'I Guess a Lot of People See Me as a Big Sister or a Friend': the role of intimacy in the celebrification of beauty vloggers. Journal of Gender Studies, 26 (3), 307-320.

Borchers, N.S. (2019). Social Media Influencers in Strategic Communication. International Journal of Strategic Communication, 13(4), 255-26o. DOI:10.1080/1553118X.2019.1634075.

Canary, D.J., \& Stafford, L. (1992). Relational maintenance strategies and equity in marriage. Communication Monographs, 59, 243-267. doi: 10.1080/03637759209376268.

Cardi B. [@iamcardib]. (2020, March 20). Day 3. [Instagram]. Retrieved July 30, 2020, from https://www.instagram.com/p/B98nknmAE64/

Carlson, M. (2007). Blogs and journalistic authority. Journalism Studies, 8, 264-270. doi:10.1080/14616700601148861

Celebrity culture. (2020). In Encyclopedia.com. Retrieved July 29, 2020, from https://www.encyclopedia.com/history/dictionaries-thesauruses-pictures-and-press-releases/celebrityculture

Chaiuk, T.A. \& Dunaievska, O.V. (2020). Producing the Fear Culture in Media: An Examination on Coronavirus Discourse. Journal of History Culture and Art Research, 9(2), 184-194. Doi: 10.7596/taksad.v9i2.2636.

Chaiuk, T. \& Karpova, K. (2021). One pandemic - four stories: Modelling the reality in British, American, Australian and Indian headlines. Science and Education. A New Dimension. Philology, 73 (248), 20-24. https://doi.org/10.31174/SEND-Ph2021-248IX73-05

Conley, M. (2020, March 31). The Great Influencer Exodus. Retrieved August 2, 2020, from https://gen.medium.com/escape-from-new-york-5725oda22561 
Cummins, E. (2020, April 22). Celebrity quarantine posts are inflaming tensions between the haves and have-nots. Vox. Retrieved July 25, 2020, from https://www.vox.com/the-highlight/2020/4/22/21228696/celebrityquarantine-coronavirus-influencer-instagram-ellen-degeneres-arielle-charnas-class-wealth

Dindia, K., \& Canary, D. J. (1993). Definitions and theoretical perspectives on maintaining relationships. Journal of Social and Personal Relationships, 10, 163-173. doi: 10.1177/026540759301000201

Dyer, R. (1998). Stars. London: BFI Publishing.

ET Canada. (2020, March 19). Gal Gadot Leads Star-Studded Singalong to 'Imagine'. [Video file]. Retrieved August 3, 2020, from https://www.youtube.com/watch?v=4sFLqGfSnVQ]

Ferreira, C. M., Serpa, S., \& Ferraz, J. (2021). Pestis: The Collective Challenges of Epidemics. Academic Journal of Interdisciplinary Studies, 10(3), 1-16. https://doi.org/10.36941/ajis-2021-0059

Fitch, K. (2017). Seeing 'the unseen hand': Celebrity, promotion and public relations. Public relations inquiry, 6 (2), 157-169. Doi: 10.1177\%2F2046147X17709064

Flanagan, H. (2020, April 2). Arielle Charnas cries over Backlash from her tone-deaf coronavirus response: 'We're not bad people!' People. Retrieved July 25, 2020, from https://people.com/style/arielle-charnas-cries-overbacklash-from-her-tone-deaf-coronavirus-response-were-not-bad-people/

Freberg, K., Graham, K., McCaughey, K., \& Freberg, L.A. (2010). Who are the social media influencers? A study of public perceptions of personality. Public Relations Review. Doi: 10.1016/j.pubrev.2010.11.001

García-Rapp, F. (2017). Popularity markers on YouTube's attention economy: The case of Bubzbeauty. Celebrity Studies, 8, 228-245. doi:10.1080/19392397.2016.1242430

Greenspan, R.E. (2020, April 2). In a tearful post from the Hamptons, an influencer apologized after fleeing NYC following her COVID-19 diagnosis. Insider. Retrieved July 30, 2020, from https://www.insider.com/ariellecharnas-something-navy-responds-to-backlash-coronavirus-2020-4

Handler, R. (2020, March 3). Are the Celebrities Okay? Vulture. Retrieved July 25, 2020, from https://www.vulture.com/2020/o3/celebrity-quarantine-social-media-ranked.html

Hartmann, T. (2016). Parasocial Interaction, Parasocial Relationships, and Well-Being. In L.Reinecke \& M.B.Oliver (Eds.) The Routledge Handbook of Media Use and Well-Being (pp.131-144). Routledge.

Hearn, A. (2008). "Meat, mask, burden": Probing the contours of the branded "self." Journal of Consumer Culture, $8(2), 197-217$.

Horton, D., \& Wohl, R. (1956). Mass Communication and para-social interaction: Observations on intimacy at a distance. Psychiatry, 19(3), 215-229.

Hudgens, V. [@VanessaHudgens]. (2020, March 17). Hey guys. I'm so sorry for the way I have offended anyone and everyone who has seen the clip from my Instagram live yesterday. I realize my words were insensitive and not at all appropriate for the situation our country and the world are in right now. This has been a huge wake up call about the significance my words have, now more than ever. I'm sending safe wishes to everyone to stay safe and healthy during this crazy time. [Twitter photo]. Retrieved August 5, 2020, from https://twitter.com/VanessaHudgens/status/1240014528366043136/photo/1

Jerslev, A. (2014). Celebrification, Authenticity, Gossip. Nordicom Review, 35, pp.171-186.

Jerslev, A. (2016). In the time of the microcelebrity: Celebrification and the YouTuber Zoella. International Journal of Communication, 10, 5233-5251 Retrieved August 5, 2020, from http://ijoc.org/index.php/ijoc/article/view/5078/1822

Kavanagh, J. (2020, March 19). Cabin fever. Sam Smith shares emotional snaps of 'quarantine meltdown' at $\$ 14 \mathrm{mln}$ home. The Sun. Retrieved August 8, 2020, from https://www.the-sun.com/entertainment/563432/samsmith-shares-emotional-snaps-of-quarantine-meltdown-at-12m-home/

Kaye, B. K. (2005). It's a blog, blog, blog, blog world: Users and uses of weblogs. Atlantic Journal of Communication, 13(2), 73-95. doi:10.1207/s15456889ajc1302_2

Khamis, S., Ang, L., \& Welling, R. (2017). Self-branding, 'micro-celebrity' and the rise of social media influencers. Celebrity Studies, 8, 191-208. doi:10.1080/19392397.2016.1218292

Kowalczyk, C., \& Pounders, K. (2016). Transforming Celebrities through social media: the role of authenticity and emotional attachment. Journal of Product and Brand Management, 25 (4), 345-356. Doi: 10.1108/JPBM-o92015-0969

Lady Gaga. [@ladygaga]. (2020, April 6). \#Chromatica 2020. [Instagram]. Retrieved August 12, 2020, from https://www.instagram.com/p/B-nQ2KYFYWF/

Lady Gaga. [@ladygaga]. (2020, March 18). Day 6 of self-quarantining! Going strong, playing video games and cards, and taking care of ourselves. Important reminder: keep your mind as stress free as possible and your body moving. \#selflove \#selfcare \#bekind try not to pass it in case you have it \#corona it's ok and so wonderful to stay home if you can!What a kind act for the world $\bullet$. [Instagram]. Retrieved August 12, 2020, from https://www.instagram.com/p/B93JykxFPBz/ 
Leonard, S., \& Negra, D. (2018). Stardom and Celebrity. In M.Kackman \& M.C.Kearney. The Craft of criticism. Critical Media Studies in Practice (pp.219-230). NY: Routledge. Doi: https://doi.org/10.4324/9781315879970

Liebers, N., \& Schramm, H. (2019). Parasocial Interactions and Relationships with Media Characters - An Inventory of 6o Years of Research. Communication Research Trends, 38 (2), 4-31.

Lopez, J. [@jlo]. (2020, March 18). We can't go out to any restaurants or anything but the service and entertainment here is pretty good... \#StaySafe \#familytime. [Instagram]. Retrieved August 5, 2020, from https://www.instagram.com/p/B94nEweJLiS/].

Lui, E. (2013, February 13). The Sociology of Gossip. [Video file]. Retrieved August 19, 2020, from https://www.youtube.com/watch?v=oFDWOXV6iEM

Lunardo, R., Gergaud, O., \& Livat, F. (2015). Celebrities as human brands: An investigation of the effects of personality and time on celebrities' appeal. Journal of Marketing Management, 31 (5-6), 685-712. DOI: 10.1080/0267257X.2015.1008548

Lustig, H. (2020, April 24). 24 times celebrities have been completely unrelatable during quarantine. Insider. Retrieved August 9, 2020, from https://www.insider.com/celebrities-quarantine-social-media-distancinghave-been-completely-unrelatable-in-2020-4

Maffucci, A. [@inspiralized]. (2020, March 19). wow. just wow. the world is a surreal place right now. time seems to have stopped completely. or at least, time seems irrelevant. we're all in this "in between”, where we don't know exactly what's going to happen. everything is unprecedented. it's all new territory. [Instagram]. Retrieved August 1, 2020, from https://www.instagram.com/p/B95UR7IFuTC/

Marshall, P.D. (2014). Persona Studies: Mapping the Proliferation of the Public Self. Journalism, 15 (2), $153-170$.

Marwick, A. (2013). Status update: Celebrity, publicity and branding in the social media age. New Haven, CT: Yale University Press.

Marwick, A., \& Boyd, D. (2011). To See and Be Seen: Celebrity Practice on Twitter. Convergence: The International Journal of research into New Media Technologies, 17 (2), 139-158.

McArdle, L. (2020, June 11). 13 celebrities diagnosed with COVID-19 and what you can learn from their experience. Everyday Health. Retrieved July 25, 2020, from https://www.everydayhealth.com/coronavirus/celebritiesdiagnosed-with-covid-19-and-what-you-can-learn-from-their-experiences/

Musk, E. [@elonmusk]. (2020a, March 6). The coronavirus panic is dumb. [Twitter]. Retrieved August 11, 2020, from https://twitter.com/elonmusk/status/1236029449042198528

Musk, E. [@elonmusk]. (202ob, March 15). Fear is the mind-killer. [Twitter]. Retrieved July 30, 2020, from https://twitter.com/elonmusk/status/1239031946962808832?s=20

Navis, N. [@taza]. (2020, March 28). ***PLEASE LOOK FOR MY UPDATE IN MY COMMENT BELOW. . [Instagram]. Retrieved August 1, 2020, from https://www.instagram.com/p/B-SjTReD-ml/

Noor, Poppy. (2020, April 10). Rihanna, Cardi B and Taylor Swift donate to fans and charities in need amid coronavirus. The Guardian. Retrieved August 2, 2020, from https://www.theguardian.com/world/2020 /apr/10/rihanna-cardi-b-taylor-swift-celebrity-donations-coronavirus

Nouri, M. (2018). The Power of Influence: Traditional Celebrity vs Social Media Influencer. Advanced Writing: Pop Culture Intersections, 32. Retrieved August 5, 2020, from https://scholarcommons.scu.edu/engl_176/32

On the Radio. (2020, April 17). Sam Smith tells Heart Breakfast Instagram post wasn't malicious or nasty. Retrieved August 19, 2020, from https://ontheradio.co.uk/2020/o4/sam-smith-tells-heart-breakfastinstagram-post-wasnt-malicious-or-nasty/

Richie, N. [@nicolerichie nicolerichie]. (2020, March 6). These are my lockdown plans. Please send me 9 thousand more recommendations. (My recommendations to you are The Great Alone, \& The Hearts Invisible Furies). Also shows and movies. Just entertain me dammit! [Instagram]. Retrieved August 13, 2020, from https://www.insta-search.net/articles/BopgsgTH3l3

Rojek, C. (2001). Celebrity. London, UK: Peaktion Press.

Rowley, Glenn. (2020, April 1). Taylor Swift continues quietly donate to fans amid coronavirus crisis. Billboard. Retrieved July 29, 2020, from https://www.billboard.com/articles/columns/pop/9348375/taylor-swiftdonations-fans-continue

Sanford, A. (2020, April 3). Coronavirus: Half of humanity now on lockdown as 90 countries call for confinement. Euronews. Retrieved July 29, 2020, from https://www.euronews.com/2020/o4/o2/coronavirus-in-europespain-s-death-toll-hits-10-ooo-after-record-950-new-deaths-in-24-hou

Senft, T. M. (2008). Camgirls: Celebrity \& community in the age of social networks. New York, NY: Lang

Shakira, I. [@shakira]. (2020, April 23). I just graduated from my 4 week Ancient Philosophy course with the University of Pennsylvania (@Penn). I know... my hobbies are very impractical, but it took a lot of hours after the kids were asleep. Thank you Plato and predecessors for all the "fun" over the past month! [Twitter]. Retrieved July 29, 2020, from https://twitter.com/shakira/status/1253351137866104834 
Sia. [@sia]. (2020, March 22). US • @dallasclayton. [Instagram]. Retrieved August 1, 2020, from https://www.instagram.com/p/B-DQT1HgLit/

Stafford, L. (2011). Measuring relationship maintenance behaviors: Critique and development of the revised relationship maintenance behavior scale. Journal of Social and Personal Relationships, 28, 278-303. doi: 10.1177/0265407510378125

Stafford, L., \& Canary, D.J. (1991). Maintenance strategies and romantic relationship type, gender, and relational characteristics. Journal of Social and Personal Relationships, 8, 217-242. doi: 10.1177/0265407591082004

Stever, G.S., \& Lawson, K. (2013). Twitter as a Way for Celebrities to Communicate with Fans: Implications for the Study of Parasocial Interaction. North American Journal of Psychology, 15 (2), 339-354

Todd, S. (2020, April 8). Tea With Me \#013 - Boyz In Da Wood WITH JAMIE DORNAN. [Video]. Retrieved August 3, 2020, from https://www.youtube.com/watch?v=3CLEtd3rC-g

Wallsten, K. (2008). Political blogs: Transmission belts, soapboxes, mobilizers, or conversation starters? Journal of Information Technology \& Politics, 4(3), 19-40. doi:10.1080/19331680801915033

Willen, C. (2020, March 23). Actress Jaime King is receiving backlash after sharing a video that "thanked" the coronavirus on Instagram. Insider. Retrieved August 5, 2020, from https://www.insider.com/jaime-kingbacklash-video-thanking-the-coronavirus-2020-3

Witherspoon, R. [@reesewitherspoon]. (2020, March 20). Friendship with social distancing. Hi @lauradern! We walked a few days ago .. before we were told to \#stayhome. Now we are inside to keep everyone safe. But I thought I would Share some of our chat in IG stories. [Instagram]. Retrieved August 5, 2020, from https://www.instagram.com/p/B99j1H4Aeif/

Younas, W., Farooq, M., \& Khalil, F. (2018). Role of celebrities and creation of brand image. Journal of Business and Management, 20 (7), 67-70. Doi: 10.979o/487X-2007026770 